\title{
THE MICROBIAL CONTRIBUTION TO HUMAN FAECAL MASS
}

\author{
Alison M. Stephen and J. H. Cummings \\ Dunn Clinical Nutrition Centre, Addenbrookes Hospital, \\ Trumpington Street, Cambridge CB2 IQE \\ Plate II
}

THE NORMAL daily faecal output in Britain is $100-200 \mathrm{~g}$ per person, of which $25-50 \mathrm{~g}$ is solid matter (Wyman et al., 1978). It is commonly thought that a major component of human faeces is undigested plant material or fibre, and that when stool output increases on addition of fibre to the diet, the increase is due to water held in the colon by this material. On an average British diet however, only $3-5 \mathrm{~g} /$ day of dietary fibre remains in the stool (Cummings $e t$ al., 1979) and, on microscopic examination, what remains appears lignified and physically inert and is unlikely to account for the water content of normal faeces.

The high nitrogen content of faeces, $6 \%$ of the dry weight (Cummings 1978), suggests that the bacterial component of faecal material may be larger than previously thought. Previous estimates of the bacterial component of the wet faecal mass are 30-40\% (van Houte and Gibbons, 1966; Moore and Holdeman, 1975). These estimates were based on direct microscopic counts which were then converted to a weight, assuming an average size for the bacteria. A more accurate method of assessing bacterial mass would be to separate the microbial fraction from the other faecal material and weigh it. We have therefore developed a method that fractionates faeces into three main components: the bacteria, undigested fibre, and soluble substances. The procedure has been developed from techniques used to isolate microbial matter from the rumen (Hoogenraad and Hird, 1970; Smith and McAllan 1974), with several steps altered or omitted to improve the separation of bacteria from fibrous debris and to ensure the purity of the bacterial fraction. By this method, a direct estimate of the microbial contribution to the weight of the stool has been obtained.

\section{MATERIALS AND METHODS}

\section{Faecal material}

The faecal material was from nine healthy male subjects aged 22-38 who were taking part in a metabolically controlled diet study (Cummings et al., 1978). In this study the subjects ate, for 3 weeks, a standard British-type diet containing $385 \mathrm{~g}$ of carbohydrate, $85 \mathrm{~g}$ of protein, $108 \mathrm{~g}$ of fat, $22 \mathrm{~g}$ of dietary fibre which provided $11.6 \mathrm{MJ} /$ day. Faeces collected during the last 7 days of the 
diet were mixed, weighed and freeze-dried in an Edwards EF6 shelf freeze dryer for 1 week. Previous tests had shown that this was the longest time required to dry weekly collections of faeces. After a week, the faeces were removed and reweighed to give a value for total faecal solids. The dried material was then crushed with a rolling pin and thoroughly mixed, and portions were taken for the fractionation procedure, for measurement of faecal neutral detergent fibre (Goering and Van Soest, 1970), and for total nitrogen determination by the Kjeldahl method. Mean transit time through the gut was measured by the continuous marker method of Cummings, Jenkins and Wiggins (1976).

\section{Fractionation procedure}

The following procedure was carried out with duplicate samples of each freeze-dried 7-day faecal collection. Into an 80-ml Stomacher bag (Stomacher 80, Colworth), 0.5 g freeze-dried faeces were weighed accurately. To this was added $30 \mathrm{ml}$ of formylsaline $(\mathrm{NaCl} 0.9 \% \mathrm{w} / \mathrm{v}$ and formalin $1 \% \mathrm{v} / \mathrm{v}$ ) and $0.3 \mathrm{ml}$ of $10 \%$ sodium lauryl sulphate (SLS). The bag and contents were thoroughly stomached for about $5 \mathrm{~min}$. and the mixture was filtered through fine nylon mesh
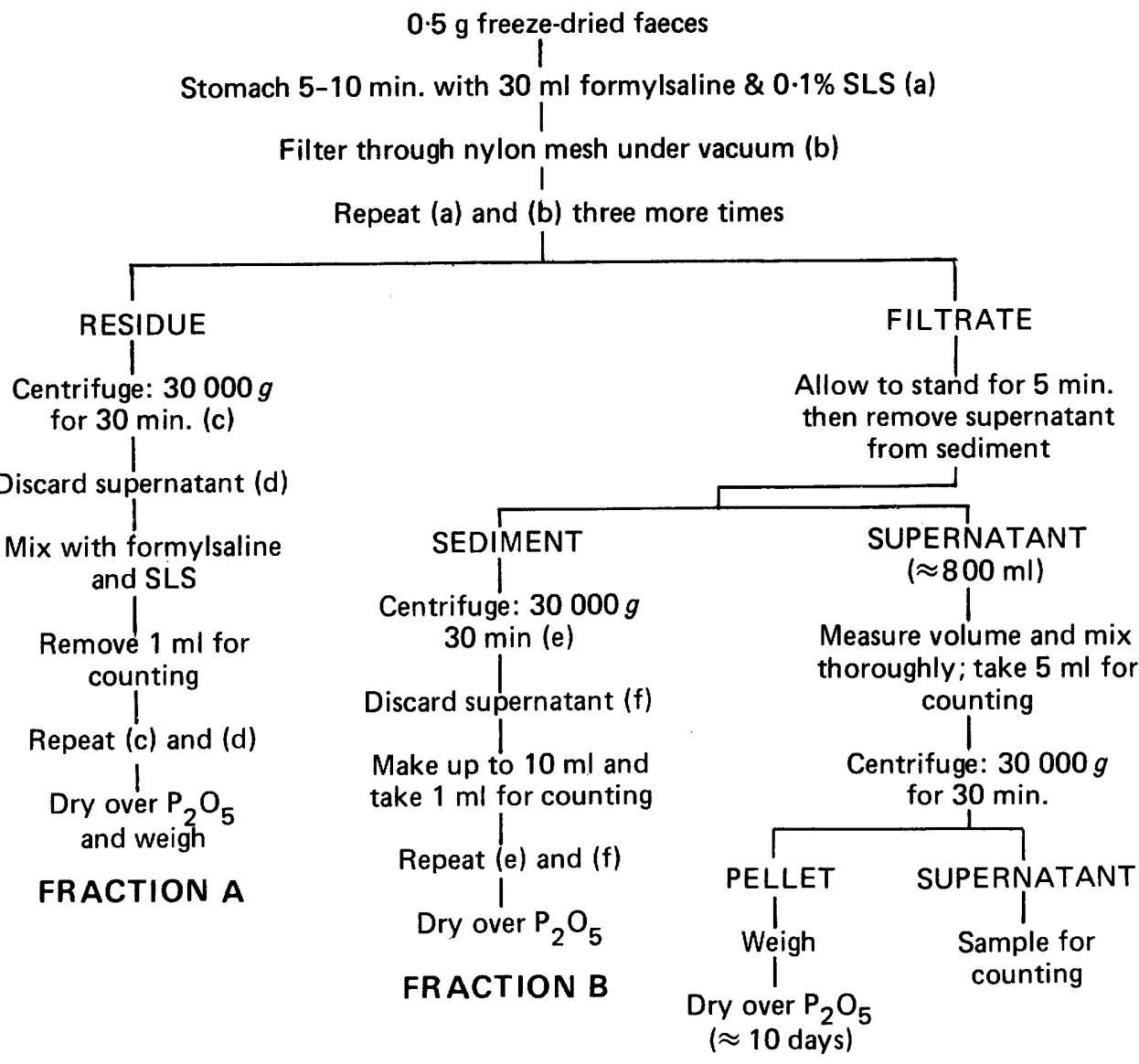

FRACTION C

FIG. 1. - Outline of technique for the fractionation of faeces into its main components. SLS = sodium lauryl sulphate 
(aperture size approximately $150 \mu \mathrm{m}$ ). Because the procedure produced considerable foaming, filtering was done under vacuum. The residue was then washed several times with formylsaline.

The residue on the nylon mesh was then washed into a second stomacher bag with another 30 $\mathrm{ml}$ of formylsaline, again with detergent, and the stomaching and filtering were repeated. This procedure was done four times in all and resulted in a residue of coarse particles retained on the nylon mesh and about $700 \mathrm{ml}$ of combined filtrate and washings.

The fibrous residue was transferred into a weighed $50-\mathrm{ml}$ centrifuge tube with formylsaline and spun at $30000 \mathrm{~g}$ (MSE HiSpin 21) for $30 \mathrm{~min}$. The supernatant was discarded and the tube weighed; $9.9 \mathrm{ml}$ of formylsaline and $0.1 \mathrm{ml}$ of SLS were added, the tube contents were thoroughly mixed in a whirlymix and a 1-ml sample was removed for microscopic counts of any bacteria present. The remainder was respun, the supernatant discarded, and the residue weighed and dried over $\mathrm{P}_{2} \mathrm{O}_{5}$. This was called fraction $\mathrm{A}$.

The $700 \mathrm{ml}$ of filtrate and washings from the separation of fraction A was noted to contain a small number of dense particles which settled out rapidly on standing. Microscopy suggested that they were simply smaller particles of fibrous debris that had passed through the nylon mesh. In ruminant work, such particles are removed by centrifuging at low speed, for example $200 \mathrm{~g}$ (Hoogenraad and Hird, 1970), but we found that this procedure also precipitated significant amounts of microbial matter. The particles were therefore removed from the fluid by leaving them to sediment for $5 \mathrm{~min}$. and then aspirating the supernatant. The sediment was washed several times in a $10-\mathrm{ml}$ tube to remove all traces of bacteria, and the washings were added to the $700 \mathrm{ml}$ of filtrate. This sediment was called fraction B and underwent the same centrifugation and sampling procedure for microbial counts as fraction $\mathbf{A}$.

The volume of the remaining suspension was noted before it was thoroughly mixed, and a $5-\mathrm{ml} \mathrm{sample}$ was taken for counting. The rest was then centrifuged at $30000 \mathrm{~g}$ for $30 \mathrm{~min}$. in $50-\mathrm{ml}$ centrifuge tubes. The supernatant was discarded and the precipitates from each tube were combined and respun. The final precipitate, called fraction $\mathbf{C}$, was weighed and then dried over $\mathrm{P}_{2} \mathrm{O}_{5}$ under vacuum to constant weight. Drying time was about 10 days for this fraction. The whole procedure is summarised in fig. 1.

\section{Water-soluble components}

The amount of water-soluble material in the freeze-dried faeces was measured by taking $0 \cdot 5-\mathrm{g}$ samples of faeces, stomaching for $5 \mathrm{~min}$. with $30 \mathrm{ml}$ of formylsaline, but without detergent, and filtering through nylon mesh. The residue was again stomached with three further lots of formylsaline and then filtrate and residue were recombined, centrifuged at $30000 \mathrm{~g}$ for $30 \mathrm{~min}$. and the supernatant removed. The pellet was dried and its weight subtracted from the original weight of material. Loss in weight was equal to the weight of the soluble component. This procedure was done in duplicate.

\section{Examination of the faecal fractions}

Light microscopy. Slide preparations for microscopy were made of fractions A, B and C. These were examined for bacteria by Preston and Morrell's (1962) modification of the Gram stain, and for plant material after staining with safranin and light green (Purvis, Collier and Walls, 1966).

Microscopic counts. To determine the proportion of the total faecal bacteria in each fraction, microscopic counts were made on the duplicate samples of fraction A, diluted 1 in 10 , and fraction $\mathrm{C}$ before centrifugation, from six subjects.

Bacteria were counted in a Helber counting chamber (Hawksley, Lancing) by phase-contrast microscopy at a magnification of 500 . For each duplicate sample, three separate portions were taken, after thorough mixing, and the bacteria present in 30 squares were counted. Therefore for each 7-day collection of faeces, six counts were done. The coefficient of variation for the triplicate counts was $26.9 \%$ (for fraction $\mathrm{C}$ ). However, the coefficient of variation between the average of these three counts for the duplicate samples was only $12.5 \%$. 
The variability in the counts was not due to observer error because when two people counted identical fields of 30 squares for six different samples the coefficient of variation was $3.3 \%$.

Electron microscopy. Fraction $\mathrm{C}$ was also examined by scanning electron microscopy. The wet pellet was prepared by dehydration through graded alcohols, $50 \%-100 \%, 1 \mathrm{~h}$ in each. It was then substituted from alcohol to liquid carbon dioxide and dried in a Polaron Critical-point Drying Apparatus. Sections from each surface of the fractured pellet were fixed to stubs with silver and sputtered with $35 \mathrm{~nm}$ of gold, in a Polaron Specimen Coating Apparatus Type E5000. The specimens were then viewed on a Cambridge S4 Scanning Electron Microscope.

Chemical analysis. The total monosaccharide content and composition in fraction $\mathrm{C}$ was determined for eight subjects. The pellet was heated in a boiling water bath with $0.5 \mathrm{M} \mathrm{H}_{2} \mathrm{SO}_{4}$. The sugars released by this procedure were estimated by gas-liquid chromatography as alditol acetates. The insoluble residue was treated with $72 \% \mathrm{H}_{2} \mathrm{SO}_{4}$ at $4^{\circ} \mathrm{C}$ for $48 \mathrm{~h}$, and the hexoses released were estimated by the anthrone method to give the value for cellulose. The nitrogen content of fractions $\mathrm{A}$ and $\mathrm{C}$ was determined by the Kjeldahl method.

\section{RESULTS}

Table I shows the means of daily faecal weight, transit time, faecal solids and excretion of neutral detergent fibre for the nine subjects whilst on the controlled diet. Faecal weight, mean transit time and excretion of faecal solids were all within the normal range for subjects of this age and sex, whilst the values for faecal neutral detergent fibre are of the same order as those for dietary-fibre excretion, measured by the Southgate's (1969) method, for four subjects on a similar low-fibre diet (Cummings et al., 1979).

Table II shows the contribution of each of the four fractions to total faecal solids. On average these four components, fractions $\mathrm{A}-\mathrm{C}$ and soluble fraction, accounted for $98 \%$ of the total solids. The coefficient of variation for duplicate samples of faeces for fraction A was $10.7 \%$ and for fraction C $2.2 \%$, indicating good reproducibility of the method.

TABLE I

Means of daily faecal weight, transit time through the gut, faecal solids and excretion of neutral detergent fibre in nine healthy male subjects on a controlled diet

\begin{tabular}{|c|c|c|c|c|c|}
\hline \multirow{2}{*}{$\begin{array}{c}\text { Subject } \\
\text { no. }\end{array}$} & \multirow{2}{*}{$\begin{array}{c}\text { Weight of } \\
\text { faeces (g/day) }\end{array}$} & \multirow{2}{*}{$\begin{array}{l}\text { Mean transit } \\
\text { time (h) }\end{array}$} & \multirow{2}{*}{$\begin{array}{l}\text { Weight of } \\
\text { faecal solids } \\
\text { (g/day) }\end{array}$} & \multicolumn{2}{|c|}{$\begin{array}{c}\text { Weight of } \\
\text { neutral } \\
\text { detergent fibre }\end{array}$} \\
\hline & & & & $\mathrm{g} /$ day & $\%$ Solids \\
\hline $\begin{array}{l}1 \\
2 \\
3 \\
4 \\
5 \\
6 \\
7 \\
8 \\
9\end{array}$ & $\begin{array}{r}65 \\
77 \\
107 \\
125 \\
66 \\
89 \\
102 \\
102 \\
102\end{array}$ & $\begin{array}{r}87 \\
89 \\
62 \\
42 \\
117 \\
80 \\
94 \\
54 \\
41\end{array}$ & $\begin{array}{l}22 \cdot 8 \\
24 \cdot 1 \\
28 \cdot 8 \\
29 \cdot 1 \\
23 \cdot 4 \\
28.3 \\
29 \cdot 6 \\
27.5 \\
28.6\end{array}$ & $\begin{array}{l}3.7 \\
4.0 \\
4.4 \\
4.1 \\
3.6 \\
5.0 \\
5.5 \\
4.1 \\
6.2\end{array}$ & $\begin{array}{l}16.2 \\
16.6 \\
15.3 \\
14.0 \\
15.4 \\
17.7 \\
18.6 \\
14.9 \\
21.7\end{array}$ \\
\hline Means & 92.8 & 74 & 26.9 & $4 \cdot 5$ & 16.7 \\
\hline
\end{tabular}


TABLE II

The proportion of daily faecal solids in nine healthy male subjects that was either soluble, or present in fraction $A, B$ or $C$

\begin{tabular}{c|rrrrr}
\hline & \multicolumn{5}{|c}{$\begin{array}{c}\text { Percentage of solids in } \\
\text { indicated fraction(s) }\end{array}$} \\
\cline { 2 - 6 } Subject no. & Soluble & A & B & C & Total \\
\hline 1 & 26.1 & 11.6 & 1.6 & 54.4 & 93.7 \\
2 & 25.4 & 13.8 & 1.8 & 59.9 & 100.9 \\
3 & 27.8 & 14.6 & 0.6 & 54.2 & 97.2 \\
4 & 16.5 & 22.0 & 1.5 & 60.2 & 100.2 \\
5 & 20.8 & 27.1 & 4.5 & 45.1 & 97.5 \\
6 & 22.9 & 19.0 & 2.9 & 58.4 & 103.2 \\
7 & 28.2 & 15.0 & 2.1 & 48.6 & 93.9 \\
8 & 21.1 & 17.6 & 2.8 & 56.8 & 98.3 \\
9 & 27.3 & 16.2 & 1.6 & 54.6 & 99.7 \\
\hline Mean & 24.0 & 17.4 & 2.2 & 54.7 & 98.3 \\
SEM & 1.3 & 1.6 & 0.4 & 1.7 & 1.0 \\
\hline
\end{tabular}

\section{Fraction $A$}

Fraction A appeared to the naked eye to be mostly plant material. When stained with safranin and light green and viewed under the microscope (fig. 2) there was a preponderance of highly lignified plant components, such as xylem and phloem and the skeletons of some whole cells.

Microscopic counts of fraction A showed that it contained only 3-4\% of the total bacteria (table III). For subjects 1, 2, 3, and 6 fraction A was less than $2 \%$ of the total count, but for subjects 4 and 5 , it was 3.8 and $8.5 \%$ respectively. This was because the separation of bacteria in the initial part of the fractionation technique was more difficult for the specimens from subjects 4 and 5 , and this is reflected in the larger bacterial count in fraction A and also (table II) in the much higher proportion of the total solids assigned to this fraction.

Total nitrogen content of the faecal solids and of fractions $\mathrm{A}$ and $\mathrm{C}$ is shown in table IV for six subjects. Faecal nitrogen averaged $1.45 \mathrm{~g}$ per day of which only $0.08 \mathrm{~g}(5.5 \%)$ was present in fraction A. This fraction was $1.9 \%$ nitrogen confirming that only a very small part of it could possibly be bacterial.

\section{Fraction $B$}

Table II shows that fraction B was only $2 \cdot 2 \%$ of the total faecal solids. Light microscopy suggested that it was made up of small irregular fragments of plant material with few bacteria. The particles were of similar size to bacteria and proved to be very difficult to separate from them during counting. Because it represented such a small proportion of the total solids, the possible microbial content of fraction $B$ has been ignored. 
TABLE III

Microscopic bacterial counts, per $g$ of faecal solids of fractions $A$ and $C$ in six subjects on identical diets

\begin{tabular}{|c|c|c|c|c|}
\hline \multirow{3}{*}{$\begin{array}{c}\begin{array}{c}\text { Subject } \\
\text { no. }\end{array} \\
1\end{array}$} & \multicolumn{2}{|c|}{$\begin{array}{l}\text { Bacterial count per } g \\
\text { of faecal solids } \pm \text { SEM in }\end{array}$} & \multirow{2}{*}{\multicolumn{2}{|c|}{$\begin{array}{c}\text { Percentage } \\
\text { of total count in } \\
\text { fraction A (mean) }\end{array}$}} \\
\hline & \multirow{2}{*}{$\begin{array}{c}\begin{array}{c}\text { fraction } A \\
\left(10^{9}\right)\end{array} \\
\begin{array}{l}6.24 \pm 0.94 \\
6.67 \pm \\
1.17\end{array}\end{array}$} & \multirow{2}{*}{$\begin{array}{c}\begin{array}{c}\text { fraction C } \\
\left(10^{11}\right)\end{array} \\
5.42 \pm 0.99 \\
3 \cdot 11 \pm 0.54\end{array}$} & & \\
\hline & & & $\begin{array}{l}1 \cdot 15^{*} \\
2 \cdot 14^{*}\end{array}$ & $(1-64) \dagger$ \\
\hline 2 & $\begin{array}{l}1.65 \pm 0.27 \\
5.02 \pm 0.48\end{array}$ & $\begin{array}{l}4.63 \pm 1.59 \\
3.72 \pm 0.72\end{array}$ & $\begin{array}{l}0.36 \\
1.35\end{array}$ & $(0.86)$ \\
\hline 3 & $\begin{array}{l}4.42 \pm 0.82 \\
2.50 \pm 0.59\end{array}$ & $\begin{array}{l}3 \cdot 16 \pm 0.52 \\
4 \cdot 39 \pm 0.19\end{array}$ & $\begin{array}{l}1.40 \\
0.57\end{array}$ & $(0 \cdot 98)$ \\
\hline 4 & $\begin{array}{l}17.06 \pm 3.21 \\
15.86 \pm 7.66\end{array}$ & $\begin{array}{l}4 \cdot 24 \pm 0.46 \\
4 \cdot 25 \pm 1 \cdot 12\end{array}$ & $\begin{array}{l}4.02 \\
3.73\end{array}$ & $(3.88)$ \\
\hline 5 & $\begin{array}{l}32 \cdot 40 \pm 12 \cdot 01 \\
30 \cdot 27 \pm 9 \cdot 11\end{array}$ & $\begin{array}{l}3.18 \pm 0.55 \\
3.55 \pm 1.66\end{array}$ & $\begin{array}{r}10 \cdot 19 \\
8 \cdot 53\end{array}$ & $(9 \cdot 36)$ \\
\hline 6 & $\begin{array}{l}9.57 \pm 1.87 \\
1.80 \pm 0.31\end{array}$ & $\begin{array}{l}3.68 \pm 0.59 \\
3.80 \pm 0.26\end{array}$ & $\begin{array}{l}2.60 \\
0.47\end{array}$ & $(1.54)$ \\
\hline
\end{tabular}

* Means of triplicate counts on each of two samples.

+ Mean of all counts.

\section{Fraction $C$}

As shown in table II, fraction C was found to be the major component (mean $54.7 \%$ ) of the faecal solids. Bacterial counts of this fraction gave a mean of $4.0 \times 10^{11} / \mathrm{gram}$ of dry faeces which, when compared to the counts in fraction A (table III), indicated that more than $95 \%$ of the total faecal bacteria were concentrated in fraction $\mathrm{C}$. The supernatant from centrifuging this component contained less than $1 \%$ of the total counts and has been ignored.

\section{TABLE IV}

Total nitrogen excretion in faecal solids and in fractions $A$ and $C$, for six subjects on identical diets

\begin{tabular}{c|cccc}
\hline & \multicolumn{3}{|c}{$\begin{array}{c}\text { Total nitrogen excretion } \\
\text { (g/day) }\end{array}$} & \multicolumn{2}{|c}{ in } \\
\cline { 2 - 4 } $\begin{array}{c}\text { Subject } \\
\text { no. }\end{array}$ & faecal solids & $\overbrace{\text { A }}^{\text {fraction }}$ & C & $\begin{array}{c}\text { Percentage of } \\
\text { total nitrogen } \\
\text { in A +C }\end{array}$ \\
\hline 1 & 1.32 & 0.04 & 0.76 & 60.6 \\
5 & 1.26 & 0.09 & 0.66 & 59.5 \\
6 & 1.66 & 0.09 & 1.08 & 70.5 \\
7 & 1.55 & 0.09 & 0.79 & 56.8 \\
8 & 1.43 & 0.13 & 0.96 & 76.2 \\
9 & 1.46 & 0.06 & 0.92 & 67.1 \\
\hline Means & 1.45 & 0.08 & 0.86 & 65.1 \\
\hline
\end{tabular}



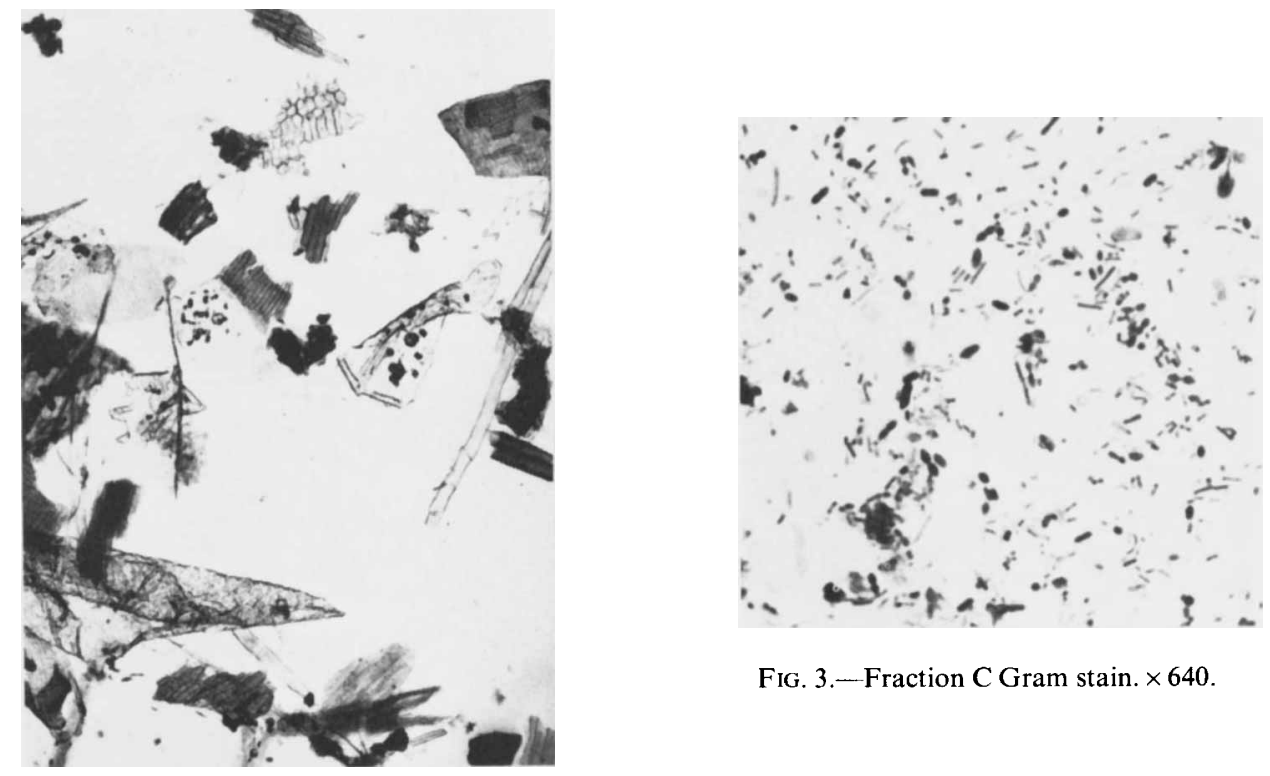

Fig. 3.-Fraction C Gram stain. $\times 640$.

FIG. 2.-Fraction A stained with safranin and light green. $\times 25$.

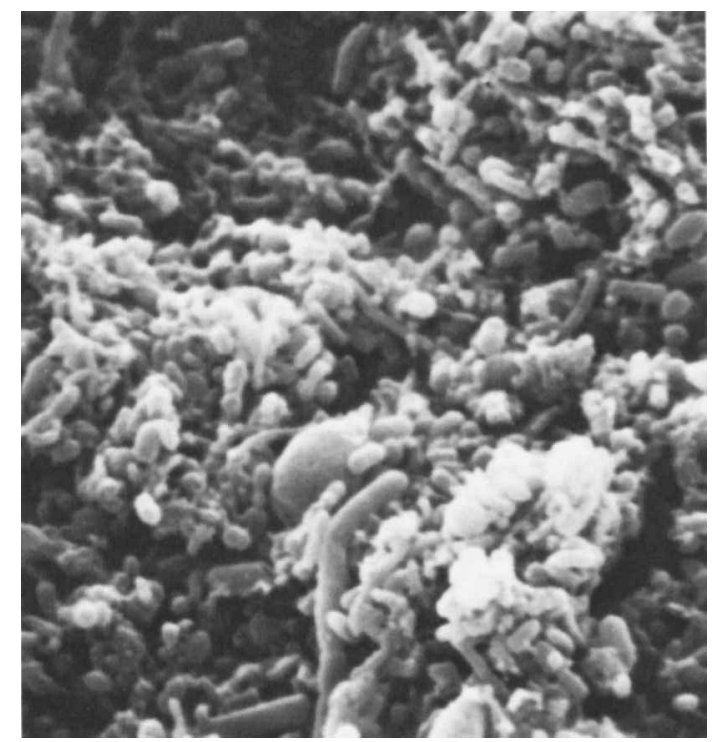

FIG. 4.--Fraction C; scanning electron microscopy. $\times 5000$. 
Having established that virtually all the faecal microflora were concentrated in fraction $\mathrm{C}$ we examined its purity in several ways. Gram stains of several samples showed the pellet to be almost entirely bacterial with only occasional fragments of fibrous debris or human cells (fig. 3). Staining with safranin and light green also revealed some plant material, lignified structures being stained dark red or black, but the general picture was of a mass stained light green, as bacteria are represented by this stain.

Scanning electron microscopy also suggested that the pellet was largely bacterial. Both the upper and lower surfaces contained small amounts of non-microbial matter but when the pellet was broken into large pieces the fractured surfaces produced appeared to be entirely bacterial (fig. 4).

Fraction $C$ was approximately $6 \%$ nitrogen, which is at the lower end of the normal range for mixed microbial populations in the rumen (Milwid, Oliver and Topps, 1968; Mason and Palmer, 1971).

Analysis of the bacterial pellet for sugars is shown in table V. The main

TABLE $\mathrm{V}$

Sugar analysis on fraction $C(\%$ dry weight $)$

\begin{tabular}{|c|c|c|c|c|c|c|c|c|c|}
\hline \multirow[b]{3}{*}{$\begin{array}{c}\text { Subject } \\
\text { no. }\end{array}$} & \multicolumn{9}{|c|}{ Percentage dry weight as } \\
\hline & \multicolumn{4}{|c|}{ hexose: } & \multicolumn{3}{|c|}{ pentose: } & \multirow[t]{2}{*}{ cellulose } & \multirow[t]{2}{*}{$\begin{array}{l}\text { total } \\
\text { sugar }\end{array}$} \\
\hline & $\begin{array}{c}\text { rhamnose } \\
\text { +fucose }\end{array}$ & mannose & galactose & glucose & ribose & arabinose & xylose & & \\
\hline 2 & 0.8 & $0 \cdot 2$ & $1 \cdot 4$ & $1 \cdot 2$ & 0.4 & $1 \cdot 2$ & $1 \cdot 2$ & 1.4 & $7 \cdot 8$ \\
\hline 3 & 1.0 & 0.2 & 1.2 & $2 \cdot 4$ & 0.5 & 1.1 & 1.1 & 2.8 & $10 \cdot 3$ \\
\hline 4 & 0.8 & 0.2 & 1.1 & $3 \cdot 3$ & $0 \cdot 5$ & 0.9 & 0.8 & 1.6 & $9 \cdot 2$ \\
\hline 5 & $1 \cdot 2$ & $0 \cdot 3$ & $1 \cdot 2$ & $1 \cdot 1$ & $0 \cdot 3$ & $1 \cdot 1$ & $1 \cdot 1$ & 1.8 & $8 \cdot 1$ \\
\hline 6 & $0 . \overline{8}$ & 0.2 & $1 \cdot 2$ & $1 \cdot 4$ & 0.4 & $1 \cdot 0$ & 0.9 & $1 \cdot 4$ & $7 \cdot 3$ \\
\hline 7 & $1 \cdot 0$ & 0.3 & $1 \cdot 3$ & $2 \cdot 5$ & 0.4 & $1 \cdot 0$ & $1 \cdot 0$ & $3 \cdot 6$ & $11 \cdot 1$ \\
\hline 8 & 1.4 & 0.2 & 1.3 & $3 \cdot 2$ & $0 \cdot 4$ & 1.2 & 1.0 & $2 \cdot 0$ & $10 \cdot 7$ \\
\hline 9 & $1 \cdot 3$ & 0.4 & $1 \cdot 7$ & $6 \cdot 8$ & 0.6 & $1 \cdot 3$ & $1 \cdot 2$ & $3 \cdot 8$ & $17 \cdot 1$ \\
\hline
\end{tabular}

object of this procedure was to show whether there was any contamination of the pellet by plant material. Arabinose and xylose, as well as cellulose, are unlikely to be of bacterial origin whereas ribose may well be. Hexose, on the other hand, could be from either bacteria or plant material (Dr H. S. Wiggins, personal communication). From the table it can be seen that the maximum contamination of the pellet with plant material, if all hexose is from fibre, would be $10 \%$. A more realistic estimate is $6-7 \%$ because some of the hexose is likely to be from bacteria.

\section{DisCussion}

Quantitation of the microbial population in human faeces may be approached in several ways. Direct microscopic counts have been used to 
estimate bacterial numbers (van Houte and Gibbons, 1966; Finegold, Attebery and Sutter, 1974) but these are subject to sampling error (Rall et al., 1970) and may underestimate total numbers, because bacteria tend to stick together and form clumps. In addition, it is difficult to extrapolate from the count to a weight of bacteria because the microbial population of the faeces contains a great variety of species, the weights of many of which are unknown.

Similar difficulties arise when chemical methods are used to determine bacterial mass, such as the determination of diaminopimelic acid (DAP). The DAP content of different species varies widely (Synge 1953; Purser and Buechler, 1966) and assumptions must be made when the weight is being converted to a mixed population. RNA has also been used as a microbial marker but even when it is rapidly degraded, as in the rumen, enough contamination remains from the diet to affect results (Smith et al., 1978); mucosal cells may also contribute to contamination.

The composition of rumen microflora has been studied by isolating bacteria by filtering and centrifugation (Hoogenraad and Hird, 1970; Smith and McAllan, 1974). This approach was also applied early in this century to the quantitation of the bacteria in human faeces and gave values of around $30 \%$ for the bacterial component of faecal solids, (MacNeal, Latzer and Kerr, 1909). Such direct methods have the advantage that no assumptions are necessary for calculation of the weight of bacteria, but because there were no ultracentrifuges at that time, the bacterial component was probably underestimated due to incomplete recovery of material from the faecal suspension.

The problem with separation techniques is that complete removal of bacteria from other material is difficult. Rumen isolation procedures do not require the complete separation of the microbial population from plant material and hence bacteria firmly associated with plant fragments are left behind. The almost complete removal of bacteria from other faecal material was achieved in the present study by the initial stomaching and filtering procedures in the presence of detergent; these steps are regarded as the key to the success of this method. Detergent, which is not used in rumen procedures, improves separation considerably. The detergent concentration used was that added to bacterial suspensions being prepared for direct microscopic counts (Meynell and Meynell, 1965) and is sufficient to reduce surface tension, without rupture of bacterial cells, as occurs with stronger concentrations of anionic detergents (Shafa and Salton, 1960).

From table III, it can be seen that only $2 \%$ of the total bacterial population was left in association with the plant fraction, fraction A. After the vigorous separation procedure with detergent, microscopic counts were subject to less error than counts on whole stools. However, the relatively high coefficient of variation $(26.9 \%)$ for counts on triplicate portions of the same sample suggest that some problems with accuracy remain. This variation was not due to observer error but more probably to difficulty in taking a representative sample of only $0.03 \mathrm{ml}$ from such a large volume and keeping the volume adequately mixed while sampling. For the purposes of comparison between the various fractions in this study counts were probably valid, although as a basis for 
extrapolating to total faecal bacterial numbers they should be used with caution.

Microscopic counts provided evidence that more than $95 \%$ of the faecal microflora had been concentrated in fraction C. It was then necessary to ensure that this bacterial fraction was not contaminated with other faecal components. Contamination of the bacterial suspension was minimised by removal of small dense particles which sedimented on standing. This fraction, $\mathrm{B}$, which was only $2 \%$ of the total solids, appeared on microscopy as small fragments of fibre or crystals.

The purity of the bacterial pellet, fraction $\mathrm{C}$, was examined by both the Gram and the plant stains which showed that only a very small amount of plant material remained. This was confirmed by scanning electron microscopy (fig. 4) which showed a densely packed bacterial mass. Chemical analysis of the sugar component of the pellet suggested that possibly $6-7 \%$ of the pellet might be plant material (table V).

No other major contaminant of the bacterial pellet was seen. Occasionally, a human cell could be seen by Gram stain, but most sloughed cells from the intestinal epithelium are probably digested by bacteria in the gut lumen and do not reach the faeces (Hoskins, 1978). Other material said to be present in faeces, such as muscle fibres, connective tissue and crystals (Stitt, Clough and Branham, 1948) were not present in fraction $\mathrm{C}$ nor were seen in significant amounts in any part of the stool.

The nitrogen content of fraction C (table IV) was $6 \%$. This value is at the lower end of the range of reported nitrogen values for mixed rumen populations (Milwid et al., 1968; Mason and Palmer, 1971). About 40\% of the faecal nitrogen in this study appears to be in the soluble fraction of the solids. This is surprisingly high although, using a similar method, Tremolieres et al. (1960) suggested $47 \%$ for soluble nitrogen. The freeze-drying process and the stomaching with formylsaline may have ruptured some of the bacterial cells, giving higher values for soluble nitrogen and lower values in the bacterial pellet.

One faecal component that has not been considered is fat. The normal stool contains about $3 \mathrm{~g}$ of fat per day (Cummings, 1978). Bacterial fat content has been found to be $10-15 \%$ for pure cultures (Luria, 1960) and $12-20 \%$ for mixed rumen populations (Czerkawski, 1976). If, as our study suggests, about $55 \%$ of faecal solids are bacteria, about $70 \%$ of the faecal fat can be accounted for by its presence in bacteria; the remaining $1 \mathrm{~g}$ is unaccounted for but may have been solubilised by the detergent. On the top surface of fraction $\mathrm{C}$ when seen by scanning electron microscopy, there appeared to be crystalline material which could be fatty acid crystals. Contamination of the pellet by fat is therefore possible but it seems unlikely that it represents a substantial proportion of it.

Fraction $\mathrm{C}$ therefore appears to be a relatively complete and pure isolate of the bacteria from human faeces and represents $55 \%$ of the total faecal solids in these subjects on a typical British diet.

The method itself is fairly time consuming, fractionation of 4-5 samples 
taking a working day. Repeated washings are necessary to ensure a good separation of bacteria from other structural material in the stool and this necessitates repeated centrifugation. Drying over $\mathrm{P}_{2} \mathrm{O}_{5}$ is also lengthy but could be shortened by freeze drying.

The proportion of faecal solids in fraction $\mathrm{A}-17.4 \%$ of the total solids - was similar to the mean neutral detergent fibre value $(16.7 \%$ ) (table I). However, faeces from subjects 4 and 5 were difficult to fractionate and even increasing the length of stomaching time and the frequency of washing could not reduce the fraction A value for subject 5 to that of the neutral detergent fibre value. Other subjects have been studied on different diets and none has presented this problem. It may therefore be less common than is suggested by the results from these nine subjects. Subject 5 had a very long mean transit time $(117 \mathrm{~h})$ with a high percentage of faecal solids $(35.4 \%)$. This may mean that the bacteria and other material were more desiccated in the stool of subject 5 and therefore associated more closely. The method may therefore be difficult in some subjects but with experience the material on the nylon mesh (fraction A) can be inspected, problems in separation detected early, and appropriate steps taken to improve it. The overall reproducibility of the method was good, particularly for the bacterial fraction.

The results obtained from this fractionation technique show that the faecal bacterial mass is larger than previously thought. If bacteria are $80 \%$ water, $55 \%$ of the dry weight becomes an even larger proportion of the wet stool, about $75 \%$. Previous studies have suggested 30\% (van Houte and Gibbons, 1966 ) or $40 \%$ (Moore and Holdeman, 1975) but these are based on conversions from microscopic counts. The mean value obtained for counts in the present study was $4.0 \times 10^{11}$ (range 2.8-6.0 $\times 10^{11}$ ) per $\mathrm{g}$ of dry faeces, which is similar to those from other studies (Finegold et al., 1974; Finegold et al., 1975; Mastromarino, Reddy and Wynder, 1978). On the basis of conversion factors used in the past, the bacterial mass as represented by the weight of fraction $\mathrm{C}$ in this study would comprise many more bacteria than are indicated by the microscopic count. This suggests that either the counts are universally low or that the conversion factors used are wrong. Recent studies of faeces have identified new species of bacteria with diameters ranging from 0.3 to $1.0 \mu \mathrm{m}$ (Gossling and Moore, 1975). Bacteria at the smaller end of this scale would not be seen easily at a magnification of $\times 500$.

The contribution of bacteria to faecal weight is therefore very considerable and approximately twice previous estimates. This finding is supported by current views of the composition of the human faeces and might explain changes in faecal weight and composition associated with varying dietaryfibre intakes. It is also possible that the colon contains a much larger mass of bacteria than hitherto thought, the metabolic consequences of which, for the host, have not been fully explored.

\section{SUMMARY}

A method has been developed, based on techniques used for isolating 
bacteria from the rumen, that enables human faeces to be fractionated into three major components. The method requires repeated, vigorous agitation of a suspension of faecal solids with detergent, the use of a stomacher, and high-speed centrifugation. By this means the faecal microflora are separated from faecal dietary-fibre residues. These two components, with water-soluble material in the stool, comprise $98 \cdot 3 \pm 0 \cdot 9 \%$ of faecal solids. The purity of the microbial fraction was demonstrated by Gram and plant stains and by scanning electron microscopy. Microscopic counts of the bacteria in each fraction of the stool showed that the microbial fraction contained $95 \%$ of the total bacteria. Chemical analysis of the component sugars indicated 6-7\% possible contamination by non-bacterial polysaccharides. The bacterial pellet was $6 \%$ nitrogen, and accounted for $60 \%$ of the total faecal nitrogen. When faeces from nine healthy subjects on a metabolically controlled British-type diet were studied, bacteria comprised $54.7 \pm 1 \cdot 7 \%$ of the total solids, fibre $16 \cdot 7 \pm 0.8 \%$ and soluble material $24.0 \pm 1 \cdot 3 \%$. Bacteria therefore represent a much larger proportion of the faecal mass than was previously thought.

We wish to thank Dr H. S. Wiggins for GLC analysis of the bacterial fraction for monosaccharides, and Mr A. J. Burgess of the Department of Zoology, University of Cambridge, for the preparation of the pellet and its examination by scanning electron microscopy. We are also grateful to Mr M. J. Hudson, Bacterial Metabolism Research Laboratory, Colindale, London for assistance with counting methodology and to Dr B. S. Drasar, London School of Hygiene and Tropical Medicine for helpful discussion throughout the project.

\section{REFERENCES}

Cummings, J. H. 1978. Dietary fibre: physiological aspects. Topics in gastroenterology, vol. 6, edited by S. C. Truelove and M. F. Heyworth. Blackwell: Oxford, p. 49.

Cummings, J. H., Jenkins, D. J. A. And WigGins, H. S. 1976. Measurement of mean transittime of dietary residue through the human gut. Gut, 17, 210.

Cummings, J. H., Southgate, D. A. T., Branch, W., Houston, H., Jenkins, D. J. A. and JAMES, W. P. T. 1978. Colonic response to dietary fibre from carrot, cabbage, apple, bran and guar gum. Lancet, 1,5 .

Cummings, J. H., Southgate, D. A. T., Branch, W., Wiggins, H. S., Houston, H. and JenKINS, D. J. A. 1979. The digestion of dietary pectin in the human gut and its relation to calcium absorption and large bowel function. Br.J. Nutr, 41, 477.

CzerkawSKI, J. W. 1976. Chemical composition of microbial matter in the rumen. J. Sci. Fd. Agric., 27, 621 .

Finegold, S. M., Attebery, H. R. And Sutter, V. L. 1974. Effect of diet on human fecal flora: comparison of Japanese and American diets. Amer. J. clin. Nutr., 27, 1456.

Finegold, S. M., Flora, D. J., Attebery, H. R. and Sutter, V. L. 1975. Fecal bacteriology of colonic polyp patients and control patients. Cancer Res., 35, 3407.

Goering, H. K. AND VAN SoEst, P. J. 1970. Forage fiber analyses. Apparatus, reagents, procedures, and some applications. Agriculture Handbook 379. US Dept of Agriculture.

Gossling, J. AND MOORE, W. E. C. 1975. Gemmiger formicilis n.gen., n.sp. an anaerobic budding bacterium from intestines. Int. J. syst. Bact., 25, 202.

HoogenRaAd, N. J. ANd HiRd, F. J. R. 1970. The chemical composition of rumen bacteria and cell walls from rumen bacteria. Br. J. Nutr., 24, 119.

Hoskins, L. C. 1978. Host and microbial DNA in the gut lumen. J. inf. Dis., 137, 694.

van Houte, J. AND GibBons, R. J. 1966. Studies of the cultivable flora of normal human faeces. Antonie van Leeuwenhoek, 32, 212. 
LURIA, S. E. 1960. The bacterial protoplasm: composition and organisation. In: The bacteria, a treatise on structure and function, edited by I. C. Gunsalus and R. Y. Stanier, vol 1. Academic Press: New York \& London, p. 1.

MacNeal, W. J., LATzer, L. L. AND KeRr, J. E. 1909. The fecal bacteria of healthy men. I. Introduction and direct quantitative observations. J. inf. Dis., 6, 123.

Mason, V. C. AND Palmer, R. 1971. Studies on the digestibility and utilization of the nitrogen of irradiated rumen bacteria by rats. J. agric. Sci., 76, 567 .

Mastromarino, A. J., Reddy, B. S. AND Wynder, E. L. 1978. Fecal profiles of anaerobic microflora of large bowel cancer patients and patients with non-hereditary large bowel polyps. Cancer Res., 38, 4458.

Meynell, G. G. And Meynell, E. 1965. Theory and practice in experimental bacteriology. Cambridge University Press: Cambridge, p. 20.

Milwid, M. S., Oliver, J. AND TopPS, J. H. 1968. The amino acid composition of rumen microbial protein from cattle grazing veld throughout the year. S. Afr. J. agric. Sci., 11, 493.

Moore, W. E. C. and Holdeman, L. V. 1975. Discussion of current bacteriological investigations of the relationships between intestinal flora, diet and colon cancer. Cancer Res., 35, 3418.

Preston, N. W. And Morrell, A. 1962. Reproducible results with the Gram stain. J. Path. Bact., 84, 241.

Purser, D. B. AND BUECHLER, S. M. 1966. Amino acid composition of rumen organisms. $J$. dairy Sci., 49, 81.

Purvis, M. J., Collier, D. C. And Walls, D. 1966. Laboratory techniques in botany, 2nd ed. Butterworth: London, p. 144.

Rall, G. D., Wood, A. J., Wescott, R. B. and Dommert, A. R. 1970. Distribution of bacteria in feces of swine. Appl. Microbiol., 20, 789.

Shafa, F. AND Salton, M. R. J. 1960 . Disaggregation of bacterial cell walls by anionic detergents. J. gen. Microbiol., 23, 137.

Smith, R. H. AND MCAllan, A. B. 1974. Some factors influencing the chemical composition of mixed rumen bacteria. Br. J. Nutr., 31, 27.

Smith, R. H., MCallan, A. B., Hewitt, D. and Lewis, P. E. 1978. Estimation of the amounts of microbial and dietary nitrogen compounds entering the duodenum of cattle. J. agric. Sci., 90, 557.

Southgate, D. A. T. 1969. Determination of carbohydrates in foods. II. Unavailable carbohydrates. J. Sci. Fd Agric., 20, 331.

Stitt, E. R., Clough, P. W. and Branham, S. E. 1948. Practical bacteriology, hematology and parasitology, 10th ed. Lewis: London, p. 850.

SYNGE, R. L. M. 1953. Note on the occurrence of diaminopimelic acid in some intestinal micro-organisms from farm animals. J. gen. Microbiol., 9, 407.

Tremolieres, J., Carre, L., Sautier, C. L., Faudemay, F., Farquet, J. and Flament, C. L. 1960. Etudes de la digestibilité chez l'homme. I. Une Méthode d'étude: le fécalogramme. Ann. Nutr. Aliment., 14, 225.

Wyman, J. B., Heaton, K. W., Manning, A. P. and Wicks, A. C. B. 1978. Variability of colonic function in healthy subjects. Gut, 19, 146. 